\title{
Development strategy of Jogja anggur agro- tourism during and post-covid-19 pandemic in Bantul, Indonesia
}

\author{
Francy R. Fivintari ${ }^{*}$, Galuh Samsi, and Muhamad Imanuddin \\ Department of Agribusiness, Universitas Muhammadiyah Yogyakarta, Jl. Brawijaya, Kasihan, Bantul \\ Yogyakarta, Indonesia
}

\begin{abstract}
The purposes of this study are to (1) identify the environmental factors that influence the development of Jogja Wine Agrotourism; (2) Formulating development strategies for Jogja Wine Agrotourism during the Covid-19 pandemic and also after the Covid-19 pandemic. Respondents chosen by the researchers were the managers of Agro Jogja Wines, visitors and the local community. The analytical method used is SWOT and QSPM analysis. The results of the study indicate that the internal factors that greatly influence the Jogja Wine Agrotourism are the characteristics of agrotourism, while the weakness is the presence of multiple workers. The main opportunity factor is the increasing demand, while the threat factor for Jogja Wine Agrotourism is the entry of newcomers in the same field. The agro-tourism development strategy that is the main priority based on the QSPM matrix analysis during the Covid19 pandemic is to maintain and strengthen the characteristics of agrotourism by providing excellent service and paying attention to health protocols in order to compete with other agro-tourism, while in the postCovid-19 pandemic, utilizing agro-tourism characteristics. Adding fruit varieties for official certification and increasing wine production so that it can become a wine development area in DIY.
\end{abstract}

\section{Introduction}

Tourism is a service industry activity and also a sector that affects the economic growth of a country [1]. Indonesia has many areas that have the potential to be developed for tourism [2], one of which is the Special Region of Yogyakarta. The Special Region of Yogyakarta was considered to be a favorite tourist destination in Indonesia, which was rich in history and traditional culture [3]. Sometime before the onset of covid-19, a number of areas in DIY opened a lot of agro-tourism, because of the economic value of production as well as ecological and educational value [4].

Agro-tourism is a form of rural tourism [5] which has very good prospects for development [6]. The purpose of agro-tourism is to expand understanding, knowledge, experience and business relations in the field of agriculture in the agro-tourism [7]. The development of agro-tourism in utilizing land and highlighting the culture in the local

\footnotetext{
${ }^{*}$ Corresponding author: francy@umy.ac.id
} 
environment increased community income and farmers' income [8]. The strategy for developing agro-tourism in Yogyakarta is to maximize the use of various existing local resources to encourage the realization of agro-tourism that is highly competitive, environmentally friendly, sustainable and can create new jobs.

In 2020 the number of foreign and local tourist visits to Yogyakarta decreased, the number of tourists decreasing was caused by the Covid-19 pandemic [9]. The Covid-19 pandemic occurred in Indonesia starting at the end of March 2020. Almost all lines were affected by this pandemic. A significant influence is the world of tourism [10]. Hundreds of hotels close due to low occupancy rate [11]. Before the Covid-19 outbreak, a number of regions in DIY opened a lot of agro-tourism, because the prospects were quite good.

One of the agro-tourism that was actually opened during the COVID-19 pandemic was Jogja Anggur Agro-tourism in Bantul. The planning and construction of the vineyard was carried out in 2018. Jogja Anggur agro-tourism opened in October 2020 while the COVID19 pandemic was still ongoing. At the beginning of the opening the level of tourist visits was quite high despite the pandemic. However, the longer the tourist visits are decreasing due to the PSBB (Large-Scale Social Restrictions) government policy that applies in the Special Region of Yogyakarta. The decrease in the number of visitors resulted in a reduction in the number of workers and double work to reduce costs incurred.

The potential that can be developed for agro-tourism is high but has not been used optimally such as the availability of untapped land, facilities and infrastructure that are not well maintained, services that are less varied and monotonous, and limited promotions. According to [4] service quality has a strong and positive relationship to visitor satisfaction while facilities and prices have a moderate and positive relationship to visitor satisfaction..

Based on some of the problems above, it was necessary to develop a development strategy by knowing several existing factors, such as the strengths, weaknesses, opportunities, and threats faced by agro-tourism [12]. Create an alternative strategy that can be applied to Jogja Anggur Agro-tourism during the Covid-19 pandemic and also after the Covid-19 pandemic, so that it is hoped that Jogja Anggur Agro-tourism more developed.

This research aims to (1) identify internal and external environmental factors that influence the development of Jogja Anggur Agro-tourism; (2) Formulating development strategies and alternative strategies for Jogja Anggur Agro-tourism during the Covid-19 pandemic and also after the Covid-19 pandemic.

\section{Research Method}

The basic method of this research is a descriptive method with a quantitative approach. Determination of the location is done purposively with specific purpose [13]. This research was conducted at the Jogja anggur Agro-tourism, which is located in Jetis, Patalan, Jetis District, Bantul Regency, Special Region of Yogyakarta. The location of this research was chosen because Agro-tourism Jogja Anggur is a new agro-tourism in the Special Region of Yogyakarta, not many people are familiar with Agro-tourism Jogja Anggur and Agrotourism Jogja Anggur is the second largest grape plantation in Indonesia. Jogja Anggur Agro-tourism has an educational agro-tourism base and has the potential to be developed, Jogja Anggur Agro-tourism has decreased the number of visitors from month to month caused by the Covid-19 pandemic.

Determination of the sample of respondent in this study was carried out using Accidental Sampling and Purposive method. Accidental Sampling is a technique based on chance, anyone who meets a researcher can be used as a sample in research [14]. Respondents in this study were 5 Jogja Anggur Agro-tourism employees selected purposively, 30 respondents were visitors and 10 respondents were local people. 
The data analysis technique used in this study consists of three stages of analysis, including i) data collection stage, ii) strategy analysis stage and iii) decision-making stage. [15]. Formulation of research development strategy using data obtained in the form of internal and external factors from agrotourism, then the factors will be entered into the IFE and EFE matrix [16]. Furthermore, the factors that have obtained a score will be used for a SWOT analysis [17] whose purpose is to formulate an appropriate alternative strategy in the development of Jogja Anggur Agro-tourism. The final step in decision making is to use the QSPM matrix which will show the main strategy for Jogja Anggur Agro-tourism.

\section{Result and discussion}

\subsection{IFE and EFE matrix analysis}

\subsubsection{Internal Factor Evaluation (IFE) matrix analysis}

IFE matrix analysis is used to evaluate the company's internal factors, where these factors will be used as a reference for future company development [18]. Identification of internal factors, namely the strengths and weaknesses of a company [19], was given a weight and also a rating by respondents who are selected or who are deemed to have information about the company. The size of the weight value given is in accordance with the level of importance of these factors affecting the development of agro-tourism. The following Table 1 is analyzes the IFE matrix:

Tabel 1. Matriks Internal Factor Evaluation (IFE).

\begin{tabular}{|c|c|c|c|c|}
\hline No & Internal Factor & Weight & Rating & Score \\
\hline \multicolumn{5}{|c|}{ Strength } \\
\hline 1 & Have a large land & 0.057 & 3.2 & 0.182 \\
\hline 2 & Varieties varies & 0.066 & 3.4 & 0.225 \\
\hline 3 & Adequate facilities & 0.058 & 3.2 & 0.186 \\
\hline 4 & Characteristic of agro-tourism & 0.066 & 3.6 & 0.239 \\
\hline 5 & Strategic place & 0.064 & 3.6 & 0.229 \\
\hline 6 & Have fruit sertification & 0.066 & 3.4 & 0.225 \\
\hline 7 & Good service & 0.066 & 3.4 & 0.225 \\
\hline 8 & New travel alternative & 0.055 & 3.2 & 0.178 \\
\hline \multicolumn{5}{|c|}{ Weakness } \\
\hline 1 & Unordered garden & 0.065 & 2.4 & 0.156 \\
\hline 2 & Lack of HR & 0.061 & 2.2 & 0.134 \\
\hline 3 & Poorly maintained facilities & 0.064 & 2.2 & 0.140 \\
\hline 4 & The occurrence of work traps & 0.057 & 2.2 & 0.125 \\
\hline 5 & Land us not maximum & 0.065 & 2.2 & 0.143 \\
\hline 6 & Lack of operational funds & 0.064 & 2.8 & 0.178 \\
\hline 7 & Lack of promotion & 0.066 & 2.2 & 0.146 \\
\hline \multirow[t]{2}{*}{8} & Less variety of educational activities & 0.060 & 2.4 & 0.143 \\
\hline & Amount & 1.00 & 45.6 & 2.854 \\
\hline
\end{tabular}

Based on the results of the Internal Factor Evaluation (IFE) analysis, it can be seen that the strength factor in Jogja Anggur Agro-tourism is contained in the agro-tourism characteristic factor with a score of 0.239 . The internal factor of weakness of Agro-tourism Jogja Anggur which has the lowest value is the occurrence of double labor with a score of 
0.125 , so that the score or factor is the most important to be improved by Jogja Anggur Agro-tourism.

The results of the IFE matrix of the strengths and weaknesses of Jogja Anggur Agrotourism get an average total value of 2.854, it showed the position of Jogja Anggur Agrotourism is quite strong or in an average position in an internal position so that Jogja Anggur Agro-tourism can maximize strengths to minimize or reduce weaknesses Jogja Anggur Agro-tourism.

\subsubsection{External Factor Evaluation (EFE) matrix analysis}

The results of the identification of external factors, namely opportunities and threats in agro-tourism, will be analyzed by an External Factor Evaluation (EFE) Matrix [20]. The following is an External Factor Evaluation (EFE) Matrix from Jogja Anggur Agro-tourism:

Table 2. External Factor Evaluation (EFE) matrix.

\begin{tabular}{|l|l|l|l|l|}
\hline No & External Factors & Weight & Rating & Score \\
\hline Opportunity & & & \\
\hline 1 & Adding Jobs & 0.0998 & 3.2 & 0.319 \\
\hline 2 & Community Support & 0.0998 & 3 & 0.299 \\
\hline 3 & Supportive Government Policies & 0.1064 & 3.4 & 0.362 \\
\hline 4 & Increasing Demand & 0.1020 & 3.8 & 0.388 \\
\hline Threat & & & \\
\hline 1 & Entry of Newcomers & 0.0909 & 1.6 & 0.145 \\
\hline 2 & Covid-19 pandemic & 0.1020 & 1.6 & 0.163 \\
\hline 3 & Visitors Choose Other Agro-tourism & 0.0953 & 2.2 & 0.210 \\
\hline 4 & Changes in People's Mindset & 0.1020 & 2.6 & 0.265 \\
\hline 5 & Covid-19 Government Regulations & 0.1020 & 1.8 & 0.184 \\
\hline 6 & Decrease in Number of Visitors & 0.0998 & 1.6 & 0.160 \\
\hline Amount & $\mathbf{1 . 0 0}$ & $\mathbf{2 4 . 8}$ & $\mathbf{2 . 4 9 4 9}$ \\
\hline
\end{tabular}

Based on Table 2 regarding external factors that become opportunities and threats of agro-tourism, the main opportunity that has the highest score is the demand for grapes to consumer needs which increases with a score of 0.388 . The most important external threats or factors in Jogja Anggur Agro-tourism to improve are the entry of newcomers in the same field with a total score of 0.145 .

\subsection{Internal External (IE) Matrix Analysis}

After the IFE and EFE analysis stages, the next stage is the internal and external matrix analysis stage. At this stage is the result of the analysis of internal and external factors that have been obtained for internal and external analysis using the IE matrix. Based on the analysis of Internal Factor Evaluation (IFE) and External Factor Evaluation (EFE) obtained a score of 2.8541 for the total internal score and 2.4949 for the total external score. The mapping of the total score of internal factors as well as the total score of external factors will describe the current state of Jogja Anggur Agro-tourism.

Based on the image of the internal external matrix (IE) above, it can be concluded that the position of the development of Jogja Anggur Agro-tourism is in cell V position with the total score obtained, namely internal 2.8541 and external 2.4949. In the cell V position, it can be interpreted that Jogja Anggur Agro-tourism is guarded and maintained, the most 
appropriate strategy for the cell position is product development, market development and market penetration to be developed by Jogja Anggur Agro-tourism

Total average IFE Score 2.8541

\begin{tabular}{|c|c|c|c|c|}
\hline & & $\begin{array}{l}\text { Strong } \\
3.0-4.0\end{array}$ & $\begin{array}{l}\text { Average } \\
2.0-2.99\end{array}$ & $\begin{array}{c}\text { Weak } \\
1.0-1.99\end{array}$ \\
\hline \multirow{3}{*}{$\begin{array}{l}\text { Total } \\
\text { average EFE } \\
\text { score } 2.4949\end{array}$} & \multirow{3}{*}{$\begin{array}{c}\text { Tall } \\
3.0-4.0 \\
\text { Intermediate } \\
2.0-2.99 \\
\text { Low } \\
1.0-1.99\end{array}$} & I & II & III \\
\hline & & IV & $\mathbf{V}$ & VI \\
\hline & & VII & VIII & IX \\
\hline
\end{tabular}

Fig. 1. IE matrix.

\subsection{SWOT analysis}

In formulating a strategy for developing Jogja Anggur agro-tourism using several alternatives, determining this alternative strategy using a SWOT matrix based on internal and external factors from agro-tourism [21]. The SWOT matrix analysis based on the results of the internal and external agro-tourism factor data can be seen in Table 3 .

SWOT analysis using internal and external factors of agro-tourism, it is known that several alternative strategies, in the formulation of this strategy, depend on each factor that exists in agro-tourism because not all factors can be used as strategies for agro-tourism. The formulation of this strategy uses each factor and often has something in common, so that the strategies can be combined and summarized in a simple way. The following is an explanation of alternative strategies for Jogja Anggur Agro-tourism:

Table 3. SWOT matrix.

\begin{tabular}{|c|c|c|}
\hline Internal factors & \begin{tabular}{l}
\multicolumn{1}{c}{ Strength } \\
1. Have a Large Land \\
2. Varieties \\
3. Adequate Facilities \\
4. Characteristics of Agro- \\
tourism \\
5. Strategic Place \\
6. Have Fruit Certification \\
7. Good Service \\
8. New Tourism \\
Alternatives \\
\end{tabular} & $\begin{array}{l}\text { Weaknesses } \\
\text { 1. Untouched Gardens } \\
\text { 2. Lack of HR } \\
\text { 3.Poorly Maintained Facilities } \\
\text { 4. Occurrence of Work Traps } \\
\text { 5. Land Utilization is Not } \\
\text { Maximum } \\
\text { 6. Lack of Operational Funds } \\
\text { 7. Lack of Promotion } \\
\text { 8. Less variety of educational } \\
\text { activities }\end{array}$ \\
\hline $\begin{array}{l}\text { Opportunities } \\
\text { 1. Adding Jobs } \\
\text { 2. Community Support } \\
\text { 3. Supportive } \\
\text { Government Policies } \\
\text { 4. Increasing Demand }\end{array}$ & $\begin{array}{l}\text { SO Strategy } \\
\text { 1. Utilizing the } \\
\text { characteristics of agro- } \\
\text { tourism, new and varied } \\
\text { fruit varieties that have } \\
\text { been officially certified } \\
\text { and increase the }\end{array}$ & \begin{tabular}{ll}
\multicolumn{1}{c}{ WO Strategy } \\
1. \\
Adding working workforce \\
(W1-W2-W3-W4-W5-O1- \\
O2) \\
2. Expanding sales and \\
promotions online by \\
collaborating with various
\end{tabular} \\
\hline
\end{tabular}




\begin{tabular}{|c|c|c|}
\hline & 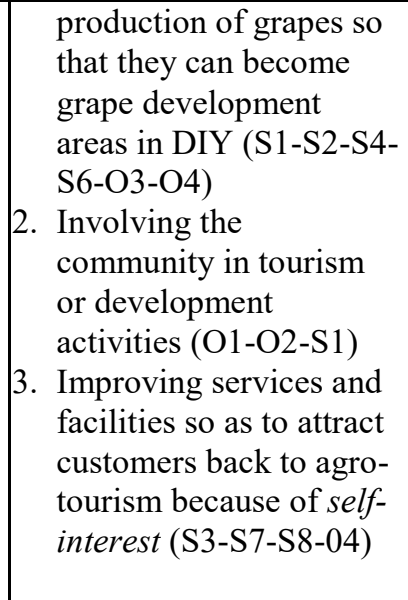 & $\begin{array}{l}\text { parties (W6-W7-O2-O3) } \\
\text { 3. Involving local } \\
\text { communities in agro- } \\
\text { tourism management (W1- } \\
\text { W4-W8-O2) } \\
\text { 4. Cooperating with the } \\
\text { government to organize an } \\
\text { event in the Bantul Regency } \\
\text { area (W8-W6-W7-O3-04) } \\
\text { 5. Maximize the land by } \\
\text { planting grapes so that } \\
\text { grapes are harvested every } \\
\text { month (sustainable) and } \\
\text { visitors can enjoy grapes } \\
\text { (W1-W5-O1-O4) }\end{array}$ \\
\hline $\begin{array}{l}\text { Threats } \\
\text { 1. Entry of Newcomers } \\
\text { 2. Covid-19 pandemic } \\
\text { 3. Visitors Choose Other } \\
\text { Agrotourism } \\
\text { 4. Changes in People's } \\
\text { Mindset } \\
\text { 6. Covid-19 Government } \\
\text { Regulations } \\
\text { 6. Decrease in the number } \\
\text { of visitors }\end{array}$ & $\begin{array}{l}\text { ST strategy } \\
\text { Maintain and strengthen } \\
\text { the characteristics of } \\
\text { agro-tourism by } \\
\text { providing excellent } \\
\text { service and paying } \\
\text { attention to health } \\
\text { protocols so that they } \\
\text { can compete with other } \\
\text { agro-tourism (S3-S4- } \\
\text { S7-T1-T2-T4-T5-T3) } \\
\text { Increase the certification } \\
\text { of grapes planted to } \\
\text { make them more varied } \\
\text { so that they can attract } \\
\text { the attention of visitors } \\
\text { (S1-S2-S6-T6) }\end{array}$ & $\begin{array}{l}\quad \text { WT Strategy } \\
\text { Maximizing promotions } \\
\text { and supporting facilities to } \\
\text { be able to compete with } \\
\text { other tours (T1-T6-T3-T5- } \\
\text { W2-W3-W4-W7) } \\
\text { Conduct online training } \\
\text { activities that can be done } \\
\text { at home (W8-T2-T4-T3). }\end{array}$ \\
\hline
\end{tabular}

\subsubsection{SO (Strengths-Opportunities) strategy}

1. Utilizing the characteristics of agro-tourism, having varied grape varieties, certified grapes, having an increasing demand for grapes, utilizing and maximizing land use because agro-tourism has a large area of land and takes advantage of supportive government support (S1, S2, S4, S6, O3 and O4). There are strengths and opportunities that are owned so that Jogja Anggur Agro-tourism is expected to be able to take advantage of the characteristics of its agro-tourism, namely by adding more varied fruit varieties and those that have been officially certified to attract the attention of visitors, maximizing land use because agro-tourism has a large area of land and can increase grape fruit production so that it is expected to be able to meet increasing consumer demand and take advantage of the support from the government so that Jogja Anggur Agro-tourism is expected to be a leading grape development area in DIY.

2. Utilizing extensive agro-tourism land, increasing job opportunities and the support from the surrounding community ( $\mathrm{S} 1, \mathrm{O} 1$ and $\mathrm{O} 2$ ) so as to produce strategies that can involve the community in tourism activities or agro-tourism development. 
3. Complementing existing facilities, improving services, increasing demand and new tourism alternatives (S3, S7, S8 and 04). These strengths and opportunities then produce alternative strategies, namely improving more excellent service to visitors, increasing existing supporting facilities in agro-tourism so that it will attract customers to return to agro-tourism because of a good impression when visiting and visitors have selfinterest to Jogja Anggur Agro-tourism so that demand will increase.

\subsubsection{WO (Weaknesses-Opportunities) strategy}

1. The condition of agro-tourism gardens that are less organized, lack of human resources, poorly maintained agro-tourism facilities, the occurrence of double labor, land use that has not been maximized, increasing employment opportunities and support from the surrounding community (W1, W2, W3, W4, W5, O1 and O2). The strengths and opportunities that exist in Jogja Anggur Agro-tourism produce alternative strategies to increase workforce to minimize existing weaknesses and maximize opportunities in agro-tourism.

2. Taking advantage of the support from the community and support from the government, lack of operational funds, lack of promotion of Jogja Anggur Agro-tourism (W6, W7, $\mathrm{O} 2$ and $\mathrm{O} 3$ ). The existence of existing opportunities and weaknesses has resulted in a strategy to expand sales and promotions online, such as sales in online applications and promotions on various social media platforms from society and government.

3. Maximizing the arrangement of gardens, the occurrence of double labor, educational activities that are less varied and support from the surrounding community (W1, W4, $\mathrm{W} 8$ and $\mathrm{O} 2$ ). These weaknesses and opportunities resulted in a strategy of involving the community in the management of Jogja Anggur Agro-tourism, this is because the activities of Jogja Anggur Agro-tourism do not involve the community much to participate in activities, the role of the community is also expected so that the education in Jogja Anggur Agro-tourism is more varied.

4. Inadequate education, lack of agro-tourism operational funds, lack of promotion, supportive government policies and increasing demand (W8, W6, W7, O3 and 04). The existence of these weaknesses and opportunities will result in a strategy of working with the government to create events in the area, with the event, agro-tourism education is expected to be more varied, the community will be more familiar with agro-tourism with events held together with the government and will also produce or increase funds for agro-tourism management so that consumer demand is also expected to be met.

5. Unorganized gardens, land use that has not been maximized, adds to employment opportunities and increased consumer demand (W1-W5-O1-O4). Maximizing land that has not been used optimally, gardens that have not been well organized with grapes planted so that every month grapes are harvested (sustainably) and visitors can enjoy grapes.

\subsubsection{ST Strategy (Strength-Treats)}

1. Maintaining existing facilities, strengthening the characteristics of agro-tourism, good service, new arrivals, the Covid-19 pandemic, visitors choosing other agro-tourism, changes in people's mindsets and a decrease in the number of visitors (S3, S4, S7, T1, T2, T3, T4 and T5). With the strengths and threats that exist, it produces a strategy that is to maintain and strengthen the characteristics possessed by Jogja anggur Agrotourism, provide more excellent service to agro-tourism visitors by observing and 
implementing applicable health protocols and establishing supporting facilities to change people's mindsets regarding the Covid-19 pandemic and can compete with other agro-tourism. The development of facilities includes the construction of gates and parking areas, information service facilities, toilets and bicycle parking, and viewing posts/gazebos, as well as bicycle lanes [22].

2. Has a large area of land, varied varieties, has fruit certification and a decrease in the number of visitors (S1-S2-S6-T6). The strengths and threats possessed by Jogja Anggur Agro-tourism resulted in a strategy of increasing the certification of grapes planted to make them more varied so that they could attract the attention of visitors.

\subsubsection{WT Strategy (Weaknesses-Threats)}

1. Lack of human resources, poorly maintained facilities, the occurrence of double labor, lack of promotion, entry of newcomers, visitors choosing other agro-tourism and government regulations (W2, W3, W4, W7, T1, T3, T5 and T6). These weaknesses and threats resulted in a strategy of maximizing promotion and supporting facilities to be able to compete with other tours.

2. Lack of varied educational activities, the Covid-19 pandemic, changes in people's mindsets and visitors choosing other agro-tourism (W8, T2, T4 and T3). Weaknesses and threats that exist in Jogja Anggur Agro-tourism have resulted in a strategy of making online-based training that can be done at home.

\subsection{QSPM Analysis}

This analysis is the basis for determining decisions in strategy, in the decision-making stage this is the last stage in this research. The stages in making this decision use the Quantitative Strategic Planning Matrix (QSPM) matrix. This matrix is used to make decisions that will determine the priorities and alternative strategies that have been formulated in the previous analysis, namely IE analysis and SWOT analysis. In this QSPM analysis, the matrix will be ranked from the highest to the lowest score.

The analysis of the Quantitative Strategic Planning Matrix (QSPM) was divided into two types, namely the analysis of the Quantitative Strategic Planning Matrix (QSPM) during the Covid-19 pandemic and after the Covid-19 pandemic, so that with the existence of these two types of QSPM matrices, it is expected to help the development of Jogja Anggur Agro-tourism. Jogja Anggur agro-tourism in the face of the Covid-19 pandemic and after the Covid-19 pandemic. The following is the Quantitative Strategic Planning Matrix (QSPM) during the Covid-19 pandemic:

Table 4. Quantitative Strategic Planning Matrix (QSPM) during the Covid-19 pandemic.

\begin{tabular}{|c|l|r|}
\hline No & \multicolumn{1}{|c|}{ Strategy } & Total Score \\
\hline 1 & $\begin{array}{l}\text { Maintain and strengthen the characteristics of agro-tourism by } \\
\text { providing excellent service and paying attention to health } \\
\text { protocols so that they can compete with other agro-tourism }\end{array}$ & 1.618 \\
\hline 2 & $\begin{array}{l}\text { Maximizing promotions and supporting facilities to be able to } \\
\text { compete with other tours }\end{array}$ & 1,243 \\
\hline 3 & Expand sales and promotions by cooperating with various parties & 0.985 \\
\hline 4 & $\begin{array}{l}\text { Improving services and facilities will attract customers back to } \\
\text { agro-tourism because of self-interest }\end{array}$ & 0.977 \\
\hline 5 & Creating online training activities that can be done at home & 0.78 \\
\hline
\end{tabular}


Based on Table 4 regarding the QSPM matrix during the Covid-19 pandemic, it can be concluded that the priority strategy in the development of Jogja Anggur Agro-tourism during the Covid-19 pandemic is to maintain and strengthen the characteristics possessed by Jogja Anggur Agro-tourism. Giving more excellent service to visitors by paying attention to and implementing applicable health protocols and establishing supporting facilities in order to change people's mindsets regarding the Covid-19 pandemic and be able to compete with other agro-tourism with the highest score of 1.618.

As for the second alternative development, namely maximizing promotions and supporting facilities to be able to compete with other tours with a score of 1,243 . With the QSPM matrix during the Covid-19 pandemic, the following is an analysis of the Quantitative Strategic Planning Matrix (QSPM) matrix after the Covid-19 pandemic, is shown in Table 5.

Table 5. Quantitative Strategic Planning Matrix (QSPM) after the Covid-19 pandemic.

\begin{tabular}{|c|l|r|}
\hline No & \multicolumn{1}{|c|}{ Strategy } & Total Score \\
\hline 1 & $\begin{array}{l}\text { Utilizing the characteristics of agro-tourism, new and varied fruit } \\
\text { varieties that have been officially certified and increase the } \\
\text { production of grapes so that they can become a wine development } \\
\text { area in DIY }\end{array}$ & 1,621 \\
\hline 2 & Adding workers who work in Jogja Wine Agrotourism & 1.316 \\
\hline 3 & $\begin{array}{l}\text { Maximizing promotions and supporting facilities to be able to } \\
\text { compete with other tours }\end{array}$ & 1,243 \\
\hline 4 & Collaborate with the government to create regional events & 1.216 \\
\hline 5 & $\begin{array}{l}\text { Make the most of the land by planting grapes so that every month } \\
\text { a grape is harvested (sustainably) and visitors can enjoy the wine }\end{array}$ \\
\hline 6 & Expand sales and promotions by cooperating with various parties \\
\hline 7 & $\begin{array}{l}\text { Improving services and facilities will attract customers back to } \\
\text { agro-tourism because of self-interest }\end{array}$ & 0.985 \\
\hline 8 & Involving the community in tourism or development activities & 0.977 \\
\hline 9 & $\begin{array}{l}\text { increase the certification of grapes planted to make it more varied } \\
\text { so that it can attract the attention of visitors (S1-S2-S6-T6) }\end{array}$ & 0.792 \\
\hline 10 & Involving local communities in agro-tourism management & 0.723 \\
\hline
\end{tabular}

Analysis of the QSPM matrix after the Covid-19 pandemic can be concluded that the strategy that is a priority in the development of Jogja Wine Agrotourism during the postCovid-19 pandemic is to utilize the existing characteristics of Jogja Wine Agrotourism by increasing grape varieties, plus new varieties and also which has been officially certified to attract more visitors' attention. Increasing grape varieties by utilizing agro-tourism land to make it more economically valuable and to maximize grape production so that it can meet increasing consumer demand or visitors, with support from the government so that it is expected to become a grape development area in DIY.

The second alternative strategy is to add labor to minimize existing weaknesses, namely unorganized gardens, lack of human resources, poorly maintained facilities, the occurrence of double labor, land use that has not been maximized and maximizing opportunities in agro-tourism, namely adding jobs and also there is support from the surrounding community with a score of 1.316 . 


\section{Conclusions and suggestions}

\subsection{Conclusion}

The internal strength factor that has the highest score is in Jogja Anggur Agro-tourism was the characteristic of agro-tourism with a score of 0.239 , while for internal weaknesses that exist in Jogja Anggur Agro-tourism namely the occurrence of double labor with a score of 0.125. External factors of agro-tourism are opportunities and threats, for opportunities for Jogja Anggur Agro-tourism was the demand for grapes to consumer needs which increased with a score of 0.388 , while for threats namely the entry of new entrants in the same field with a total score of 0.145 .

The agro-tourism development strategy was the main priority based on the QSPM matrix analysis during the Covid-19 pandemic is to maintain and strengthen the characteristics of agro-tourism by providing excellent service and paying attention to health protocols so that they can compete with other agro-tourism with a score of 1.618 , while post-Covid-19 pandemic, namely Utilizing the characteristics of agro-tourism, varied and new fruit varieties that have been officially certified and increasing the production of grapes so that they can become a grape growing area in DIY with a score of 1.621 .

\subsection{Suggestion}

Jogja Anggur Agro-tourism should maintain internal factors that are the strengths of Jogja Anggur Agro-tourism to minimize weaknesses that can hinder the development of Jogja Anggur Agro-tourism.

Jogja Anggur Agro-tourism can implement strategies from the results in the form of product improvement, promotion, supporting facilities to be able to compete with other agro-tourism.

\section{Reference}

1. W. A. Risso, Tourism and Economic Growth: A Worldwide Study, Tour. Anal. 23, 123 (2018).

2. J. Sihite and A. Nugroho, Exploring the Indonesian Tourism Destination via Indonesia.Travel @indtravel, in 2nd Int. Conf. Tour. Gastron. Tour. Destin. (ICTGTD 2018) (atlantis-press.com, 2018).

3. N. A. Aziz, I. Muslichah, and A. H. Ngah, Understanding factors influencing community life satisfaction towards sustainable heritage tourism destination: The case of Yogyakarta, Indonesia, J. Sustain. Sci. Manag. 15, 37 (2020).

4. I. Santoso and H. J. Nadapdap, Hubungan Fasilitas, Kualitas Pelayanan, Harga Dan Tempat Terhadap Kepuasan Pengunjung Agrowisata Di Pt Perkebunan Tambi, Kabupaten WonosoboJ. Sos. Ekon. Pertan. 15, 135 (2019).

5. C.-R. VÎNTU, I. N. Alecu, A. Chiran, E. Leonte, A.-F. JITĂREANU, and M. ŞTEFAN, Researches on the agrotouristic offer of guest houses in Dornelor bassin (case study), Int. J. Conserv. Sci. 8, 419 (2017).

6. L. Sahin and D. Sahin, Agro-Tourism Applications in the Context of Rural Development: Evidence from Emerging and Developed Countries, in Int. Conf. Food Agric. Econ. (2017).

7. N. N. D. Adnyani, N. W. Sukerti, and L. Masdarini, Strategi Pengembangan Agrowisata Salak Di Desa Sibetan Kabupaten Karangasem, Bosaparis x, (2013). 
8. A. Widyawati, A. Naufal, A. C. Hidayah, and B. Hidayati, Pembangunan Agrowisata Berbasis Kearifan Lokal dan Nilai Pancasila dalam Mewujudkan Sustainability Agricultural Systems, in Semin. Nas. Ekon. Pembang. (2021), pp. 274-279.

9. Y. M. Prakoso and B. Ramadhika, The Comparative Study Between The Effect Of COVID-19 And Earthquake Disaster On Tourism Attraction In Yogyakarta, J. Bus. Hosp. Tour. 06, 132 (2020).

10.M. Prastuti, L. Aridinanti, and W. P. Dwiningtyas, Spatio-Temporal models with intervention effect for modelling the impact of Covid-19 on the tourism sector in Indonesia, J. Phys. Conf. Ser. 1821, (2021).

11.Isdarmanto, D. R. Susanto, and A. Kiswantoro, Tourism Branding: A Strategy of Regional Tourism Sustainability Post COVID-19 in Yogyakarta, in IOP Conf. Ser. Earth Environ. Sci. (IOP Publishing, 2021).

12.H. T. Soelistyari, R. Alfian, and D. Budiyono, Strategi Pengembangan SWOT Agrowisata di Desa Pandansari Lor, Kabupaten Malang, Buana Sains 20, 149 (2020).

13. Suryabrata, Metode Penelitian (Raja Grafindo Persada, Jakarta, 2003).

14.Sugiyono, Metode Penelitian Kuantitatif, Kualitatif Dan R\&D, 20th ed. (Alfabeta, Bandung, 2014).

15.A. M. Kiloes, Puspitasari, M. J. A. Syah, and B. K. Udiarto, Strategy for Potato Seed Farming Development in Kerinci Regency, Agrar. J. Agribus. Rural Develpoment Res. $5,(2019)$.

16.R. Kurniawati and N. Marlena, Analisis SWOT Sebagai Dasar Perencanaan Strategi Pemasaran Pada Agrowisata Belimbing Karangsari Kota Blitar, J. Manaj. Dan Bisnis Indones. 6, 191 (2020).

17.N. H. Fadhillah and I. Heru, SWOT Analysis and Risk Assessment Matrix on Garlic Seed Farming in Karanganyar, Russ. J. Agric. Socio-Economic Sci. 93, (2019).

18.E. GURL, SWOT Analysis: A Theoretical Review (demo.dspacedirect.org, 2017).

19.J. W. Bull, N. Jobstvogt, A. Böhnke-Henrichs, A. Mascarenhas, N. Sitas, C. Baulcomb, C. K. Lambini, M. Rawlins, H. Baral, J. Zähringer, E. Carter-Silkk, M. V. Balzan, J. O. Kenter, T. Häyhä, K. Petz, and R. Koss, Strengths, Weaknesses, Opportunities and Threats: A SWOT analysis of the ecosystem services framework, Ecosyst. Serv. 17, 99 (2016).

20.H. Thamrin, R. Herlambang, B. Brylian, K. A. Aldino, Gumawang, and A. Makmun, A SWOT analysis tool for Indonesian small and medium enterprise, ARPN J. Eng. Appl. Sci. 12, (2017).

21.I. Petroman, C. Suciu, M. C. Benea, R. Bolocan, and D. Marin, SWOT Analisys of Banat and Timis Agrotourism Sector, in 3rd Int. Multidiscip. Sci. Conf. Soc. Sci. Arts SGEM 2016 (elibrary.ru, 2016).

22.I. K. Sardiana, The Study of Development of Urban Farming Agrotourism SubakIrrigation-Based in Sanur Tourism Area, Denpasar City, Bali, J. Indones. Tour. Dev. Stud. Vol.6, (2018). 